\title{
THE ROLE OF VENEZUELAN SPACE TECHNOLOGY IN PROMOTING DEVELOPMENT IN LATIN AMERICA
}

\author{
J.A. Pena ${ }^{\mathrm{a}}, \mathrm{T}$. Yumin ${ }^{\mathrm{b}}$, \\ ${ }^{\mathrm{a} b}$ School of Transportation Science \& Engineering, Beihang University Beijing, China \\ ajpena@abae.gob.ve ${ }^{\mathrm{b}}$ tany@buaa.edu.cn
}

KEY WORDS: Space technology; Training program; Latin America; International cooperation.

\begin{abstract}
:
Space technology and resources are used around the world to address societal challenges. Space provides valuable satellite services, unique scientific discoveries, surprising technology applications and new economic opportunities. Venezuela formally recognizes the advantages of space resources and pursues national level activity to harness them. Venezuela space cooperation has grown in the past several years, contributing to debates over Venezuela's rising influence in the Latin America. This paper summarizes the establishment and current development of space activities in the Bolivarian Republic of Venezuela, these activities are focused on the areas of telecommunications, Earth observation, research and development space and has as a primary goal the satisfaction of social needs. This analysis offers the elements most important of the Venezuelan space policy: technological transfer, capacity building and human training and international cooperation including the new participation of Venezuela in the international charter on space and major disasters. Our analysis shows that Venezuela has the potential to become a space leadership country, promoting the social welfare, integration, and sustainable development of Latin American countries.
\end{abstract}

\section{INTRODUCTION}

It is well known that the peaceful uses of outer space provide a powerful tool for furthering the well-being of humanity and the Earth's environment. Space science and technology, products and services are used by everyone around the world: the role played by earth observation satellite.

The Venezuelan space program began in 1999 and by 2007 the Bolivarian Agency of Space Activities (ABAE) had been established. Initial programs, focused on telecommunications and remote sensing, have emphasized capacity building, with the goal of eventually leading to the indigenous development of satellites in support of both national and regional needs. [1].

Venezuela has taken big steps in relation to their spatial technology, is looking to become a more relevant player in this market, with two satellites already launched and another one will be launch in September 2017 (VRSS-2) and builds of a Centre of research and development space (CIDE) focused on building small satellites of up to 1 ton in weight [2], carried out more ambitious space projects in the pipeline, the country is quickly becoming a pioneer for developing a space-based capability in Latin America.

In 10 years, the country has already launched two satellites, trained more than 3540 professional with satellite technology skills including professionals from Latin America, signed more that 10 Memorandum of understanding and cooperation agreements and is almost ready the Centre of research and development space [3].
At the end of 2008 Venezuela launched its first telecommunications satellite, built in cooperation with China, which operates in the $\mathrm{C}$ (covering Central America, the Caribbean Region and most of South America), Ku (Bolivia, Cuba, Dominican Republic, Haiti, Paraguay, Uruguay, Venezuela) and Ka bands (Venezuela); on September 29, 2012 was launched the first Venezuelan Remote Sensing Satellite (VRSS 1), carries two cameras with a resolution of 2.5 meters in panchromatic mode (PAN) and 10 meters in multispectral mode (MS), and two cameras with a combined resolution of 16 meters, both satellite have provided help for the countries of Latin America and have made many international agreements related to education, scientific application, environmental protection, disaster monitoring and management, security and defense, etc. Using published and unpublished information this report describes the potential role of the Venezuelan space technology in promoting development in Venezuela and Latin America.

The Venezuelan space program in the last 10 years is shown below:

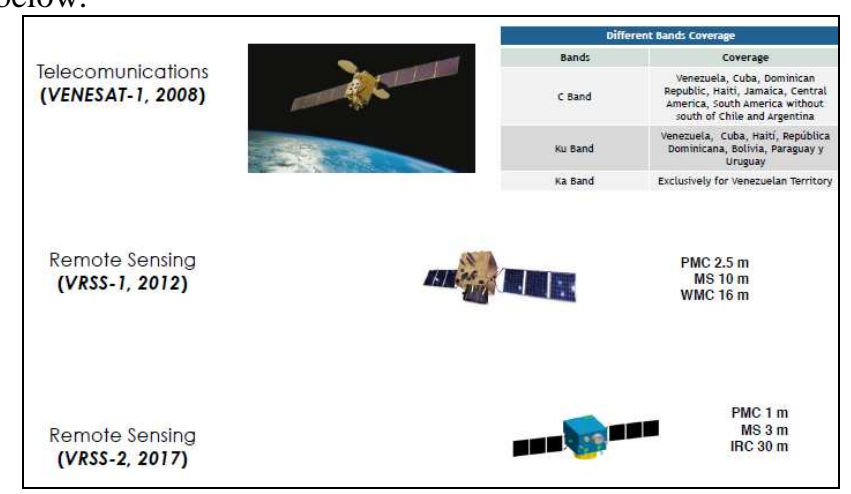

Figure $\mathrm{N}^{\circ} 1$ : Venezuelan space program. Source: M. Imbert (ABAE) 


\section{FINANCING AND TECHNOLOGY TRANSFER}

These are crucial issues for ensuring that the spatial policy goals and international commitments result in effective action. In Latin America cooperation in this area is crucial because it allows taking into consideration the specific characteristics of local situations. Financing is a priority issue in moving towards sustainability in all areas covered in space technology. In many cases, international agreement has been reached, and national policies have been established, but without adequate financing to ensure their implementation.

In Venezuela case the financial cooperation (including technology transfer) has been a key element in promoting spatial activities. [4].

The importance of international technology transfer for economic development can hardly be overstated. Both the acquisition of spatial technology and its diffusion foster country growth. Most developing countries must rely largely on imported technologies as sources of new knowledge. In this sense China has provided great support to many countries in Latin America in the spatial development

Technology transfer and human capital development are critical Venezuelan policy goals, as well as international space cooperation is deemed a priority Officials have described cooperation as crucial for strengthening research capability and generating new knowledge and as a tool for development. Nevertheless, cooperation must be closely tied to the foreign policy goals of the state, such as strengthening national sovereignty, promoting a multipolar world order, furthering the integration of a Latin American community of nations and promoting cooperation among developing countries. [5].

Latin American space technology is increasing in the last years; nevertheless, the development of home-grown space technology in Latin America can be defined as both a shortterm and a long-term project for many nations.

For more than 10 years China and its space industry, have been the main partner for the main Venezuelan space projects from the beginning, it has been an important player in its development and may continue acting as one of the most important partners not only for the future Venezuelan aerospace industry but also other Latin-American countries' aerospace industries. [6].

The Venezuelan space technology has been of great aid to Latin American countries, improving telecommunication capabilities to isolated areas, promoting spatial education as well as monitoring environmental conditions.

The Venezuelan satellites have boosted several industries related to the satellite market, including bringing telephone, high-speed internet and TV services to isolated areas in the country and the border.

Based within the framework of South - South cooperation promoted by the Venezuelan Government, the telemedicine networks have been spread to most of the countries in Latin America and the Caribbean Region. [7].

\section{STRENGTHENING TRAINING PROGRAM}

The main principles of space activities in Venezuela are to promote the development and growth of space capabilities through technology transfer and human training in order to achieve technological independence, coordinate and use space science and technology to satisfy social needs and support national programs and promote regional and international cooperation. [8].

In order to execute its educational programmes, $\mathrm{ABAE}$ conducts a series of seminars, workshops and conferences. The education programmes serve to disseminate knowledge in the field of space science and technology to benefit countries in the región. Below is showed an information statistics highlighting the importance of education in the spatial field.

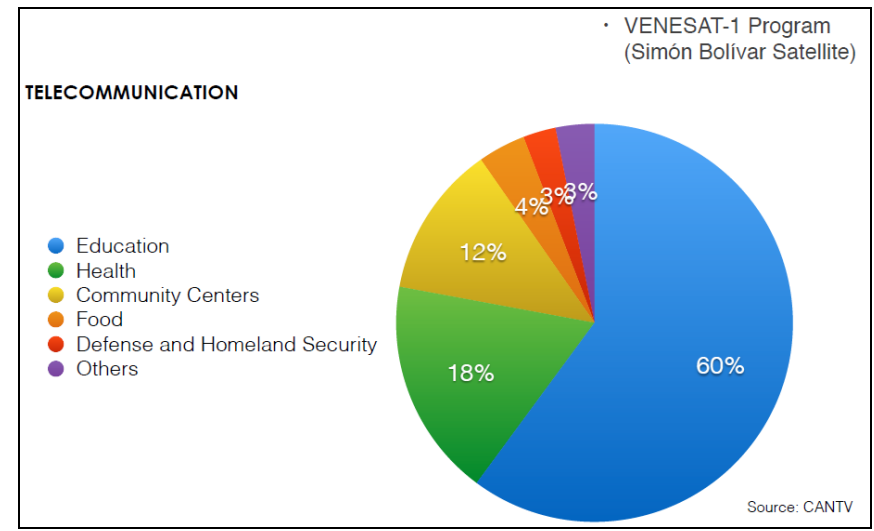

Figure $\mathrm{N}^{\circ}$ 2: Space communication application in Venezuela. Source $\mathrm{M}$ Imbert (ABAE)

The Venezuelan space program has served to strengthen training in areas of Earth observation and communications, for that reason, Venezuela has developed programs to help make the use of remote sensing data more widespread. The ABAE has played a major role in spurring programs that use remotely sensed data for various educational programs of the spatial agencies in Latin America including exchange of experiences in digital image processing.

This course has been taught to the ABAE's professional of the as part of programs of training of human resources of the institution, as well as professionals of the National Commission of Space Activities (CONAE) and Bolivian Space Agency (ABE), representing the first specialized in the subject course taught in Spanish language. [9].

One of the goals in the space activities is positioned as a regional bloc with Latin America and the Caribbean in different areas of knowledge and one of them, of course, is the space activity. Cano says. "Our idea is to strengthen ourselves as a nation in the space industry but also rely on other countries within the region, such as Argentina and Brazil, which have already built several satellites and have more years of experience than us. In addition, we also support other countries, such as Bolivia, that are starting to delve in the space industry. We seek to establish a relationship both to 
obtain new knowledge, as well as to provide new knowledge to the region." [10].

Human training to date is one of the main achievements of the government and ABAE has been the training of 3544 local professionals in different fields of space science and technology, including training in other countries [11].

Space activity has increased considerably in the Latin America and Caribbean region. Several countries have established, or are in the process of establishing, space agencies or similar bodies to coordinate national space activities. Government institutions are increasingly using space technology to carry out national and local plans for sustainable development, including protection of the environment and disaster reduction. Through international cooperation the academic community is participating in basic research in many areas of space science and exploration.

The Venezuelan space policy aims to promote and build awareness of the benefit is of space science and technology and their applications by organizing conferences, seminars and workshops in this field.

\section{INTERNATIONAL SPACE COOPERATION}

The capacity of satellite remote sensing and satellite technology is distributed quite disproportionately in the world. As of November 2015, only 74 countries have been able to make satellite launches independently or with the help of others. [12].

Currently space technology is very important for the decision making process, but although remote sensing data has a potential for science-based decision-making on different field such as disaster management, global environment, and management of natural resources, not all users (policy makers, academic institutions, organizations in Latin America) have the necessary technical background and knowledge to understand, download, and manipulate the data according to their needs, for this reason the international agreement and cooperation are necessary to exchange experiences, knowledge and technology.

The 1999 Constitution of the Republic Bolivarian of Venezuela, for example, describes international relationships as being ordered by principles of independence, equality, and non-intervention, the peaceful resolution of disputes and solidarity among countries. [13]

In this sense the international cooperation of Venezuela through the ABAE aims to consolidate the plans, programmes and projects in the space field promoted by the national Government, favoring those of social and regional scope. Activities of international cooperation include:

- Negotiation and signing of international instruments of cooperation at the bilateral and multilateral level (treaties, agreements, conventions; Letters of intent; Memorandum of understanding, joint statements).

- Negotiation and execution of scientific and technological projects and programmes.

- International Participation settings (forums, workshops, courses, conferences, seminars).

- Training of human talent and exchange of experiences, etc.

The Bolivarian Republic of Venezuela has signed instruments of Bilateral Cooperation in the space field and peaceful use of outer space, with the following Latin America countries:

\section{A. Oriental Republic of Uruguay}

Agreement in the development of the VENESAT-1 program for the use $78^{\circ}$ orbital position requested by Uruguay for the program URUSAT-3, between Uruguay and Venezuela. Signed on May 14, 2006.

Uruguayan and Venezuelan professional training, in the framework of the VENESAT-1 program, to monitoring and management of the ground station, located in Manga-Uruguay.

\section{B. Federative Republic of Brazil}

Framework of cooperation agreement in space science and technology between the Venezuela and the Government of the Federative Republic of Brazil. Signed on June 27, 2008.

Memorandum of understanding to allow scientific and technological training in the geomatics field and spatial engineering and geoscience, between the Ministry of the Popular power for science and technology of the Bolivarian Republic of Venezuela and the Ministry of science, technology and innovation of the Federative Republic of Brazil. Signed on November 01, 2011.

Twenty one (21) Venezuelan professionals were trained in the "international course in remote sensing and geographic information systems", developed by the National Institute of space research (INPE) of Brazil.

\section{Republic of Argentina}

Framework of cooperation agreement on peaceful uses of outer space, science, technology and space applications between the Government of the Bolivarian Republic of Venezuela and the Government of the Republic of Argentina. Signed on December 1, 2011.

Specific cooperation agreement in the satellite field between the Ministry of science, technology and innovation in the Bolivarian Republic of Venezuela through of ABAE, and the Ministry of Federal Planning, public investment and services of the Republic Argentina, through the National Commission of space activities (CONAE). Signed on May 8, 2013. 


\section{Plurinational State of Bolivia}

Memorandum of understanding between the Government of the Bolivarian Republic of Venezuela and the Government of the plurinational State of Bolivia to the spatial development and training. Signed on March 31, 2011.

Cooperation agreement on scientific application training and physical modeling. Signed on May 26, 2013. In this sense 103 Bolivian professionals were trained by Venezuelan instructors in the remote sensing field.

\section{E. United States Mexican}

Cooperation agreement on science, technology and space innovation for the use of outer space for peaceful purposes between ABAE - Venezuela and Mexican Space Agency (AEM) of the United States of Mexico. Signed on September $17,2015$.

50 Mexican professionals trained by Venezuelan instructors through of distance learning course "Remote sensing applied to the evaluation of the environment geographical in educational field"

These cooperation agreements and their outcomes demonstrate that Venezuela is willing to actively participate in the space arena as a peaceful nation, promoting the integration and sustainable development of Latin American countries which share similar cultural, social, economic, political, and environmental realities [14]. These cooperation and alliances have enabled the rapid growth of Latin America in the space field and currently is promoting the creation of the Agency space Latin American and Caribbean.

For Venezuela international cooperation is a real integration tool (regional and transcontinental) that is helping it build its space capabilities. This kind of strategic alliance is perceived by member states as a win-win policy, which integrates regional and international space aspirations and development for peaceful purposes.

\section{VENEZUELA SPACE ACTIVITIES IN THE FRAME OF THE}

\section{INTERNATIONAL CHARTER ON SPACE AND MAJOR DISASTERS}

The Charter was initiated in 1999 following the UNISPACE III conference held in Vienna, Austria in 1999. The Charter aims at providing a unified system of space data acquisition and delivery to those affected by natural or man-made disasters through Authorized Users. Each member agency has committed resources to support the provisions of the Charter and thus is helping to mitigate the effects of disasters on human life and property.

The Charter closely collaborates with a great number of international organizations to achieve better coordination in the issue of space technologies application for disaster effects mitigation (UNSPIDER, UNOOSA, Sentinel Asia).
The space activity of Venezuela recently reached a significant recognition to distinguish itself as the third country in Latin America to join the International Charter on space and major disasters and one of the few Nations in the world that has advanced rapidly (10 years )in the space field. [15].

$\mathrm{ABAE}$ has provided to countries affected by some natural disaster most of 382 images VRSS-1, [16]. A table is shown below:

TABLE I. IMAGES PROVIDED TO DIFFERENT COUNTRIES

\begin{tabular}{|c|l|c|c|c|}
\hline \multirow{2}{*}{ COUNTRY } & \multirow{2}{*}{ CAUSE } & \multicolumn{2}{|c|}{ SENSOR } & \multirow{2}{*}{ DATE } \\
\cline { 3 - 4 } & & $\boldsymbol{P A N}$ & $\boldsymbol{M S S}$ & \\
\hline Nepal & Earthquake & 8 & 8 & APR, 2015 \\
\hline Ecuador & Earthquake & 47 & 49 & APR, 2016 \\
\hline Unites Estates & Floods & 18 & 24 & APR,AGO, 2016 \\
\hline China & Floods & 40 & 44 & JUN, 2016 \\
\hline Australia & Floods & 18 & 18 & OCT, 2016 \\
\hline India & Cyclone & 1 & 1 & DIC, 2016 \\
\hline Russia & Fire & 35 & 36 & DIC, 2016 \\
\hline Costa Rica & Floods & 3 & 4 & DIC, 2016 \\
\hline Chile & Fire & 10 & 11 & JAN, FEB, 2017 \\
\hline Argentina & Fire & 3 & 4 & JAN, 2017 \\
\hline $\begin{array}{c}\text { NUMBER OF } \\
\text { IMAGES }\end{array}$ & & 183 & 199 & \\
& & & & \\
\hline
\end{tabular}

ABAE provides the Data from VRSS-1 satellites and Archive according to ABAE data policy and delivers the Earth Observation Data of Level 2B processing inconformity with international norms and standards.

\section{A. ABAE Contribution to the Charter:}

- $\quad$ Provides the Charter Authorized Users with an access to satellite data with processing level $2 \mathrm{~A}$ and $2 \mathrm{~B}$ acquired from VRSS-1 and from the remote sensing data archives.

- Appoints representatives to the Charter Board and the Executive Secretariat.

- The Center staff perform the following functions:

- Emergency On-Call Officer (ECO), that operates 24 hours a day when ABAE is on duty in the Charter;

- Project Manager;

- Communication Representative

B. Application for emergency monitoring tasks:

- Forest fires monitoring;

- Flood monitoring;

- $\quad$ Oil spills monitoring;

- Infrastructure destruction assessment of disasteraffected cities;

- $\quad$ Earthquake;

The images of the Venezuelan satellite according their technical parameters and image quality has been very useful in the monitoring of natural disasters. Fig. 3, 4, 5, 6 and 7 shows some images and products provided by Venezuela to different countries that have required the charter activations: 


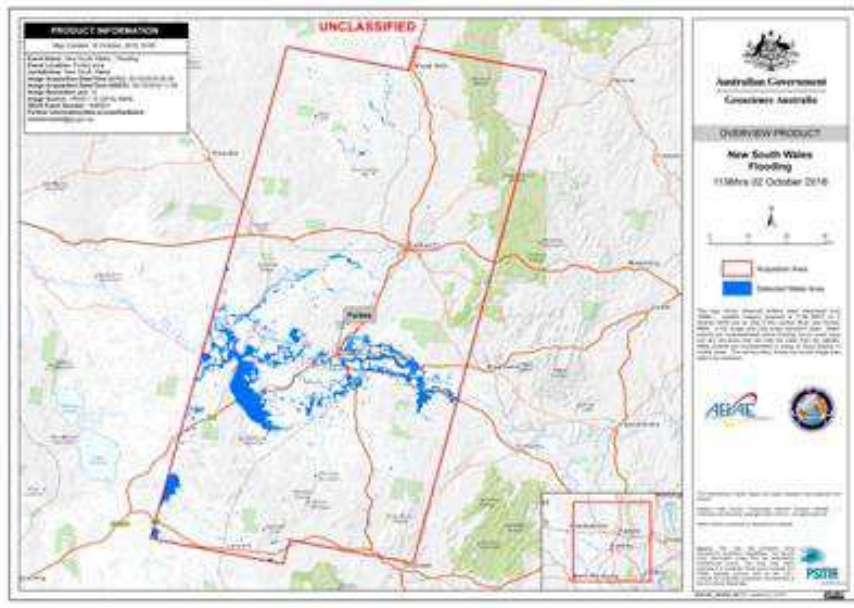

Figure $\mathrm{N}^{\circ}$ 3: New South Walles Flooding - Australia, Oct, 2016, using VRSS.1

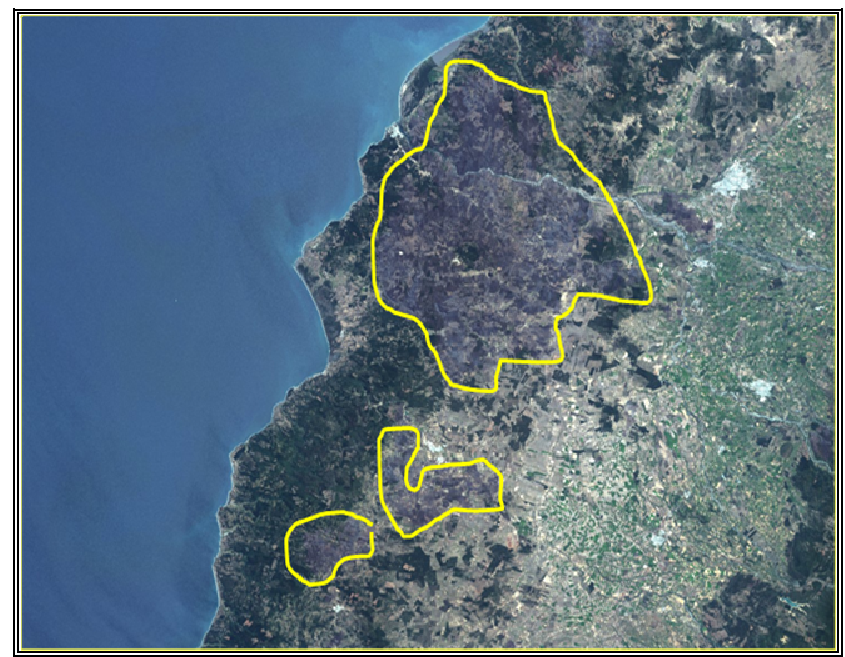

Figure $\mathrm{N}^{\circ}$ 4: demarcated areas affected by Fire - Chile, Feb, 2017, using VRSS.1

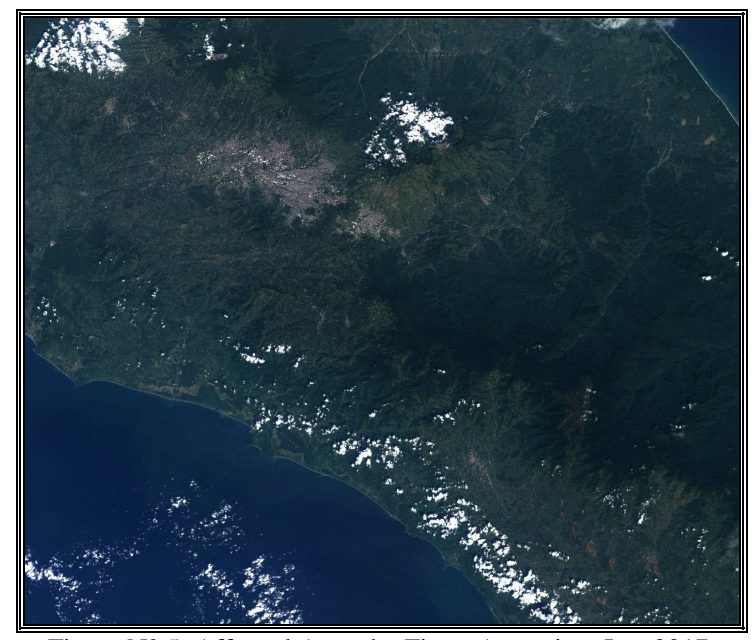

Figure $\mathrm{N}^{\circ}$ 5: Affected Areas by Fire - Argentina, Jan, 2017, using VRSS.1 Image

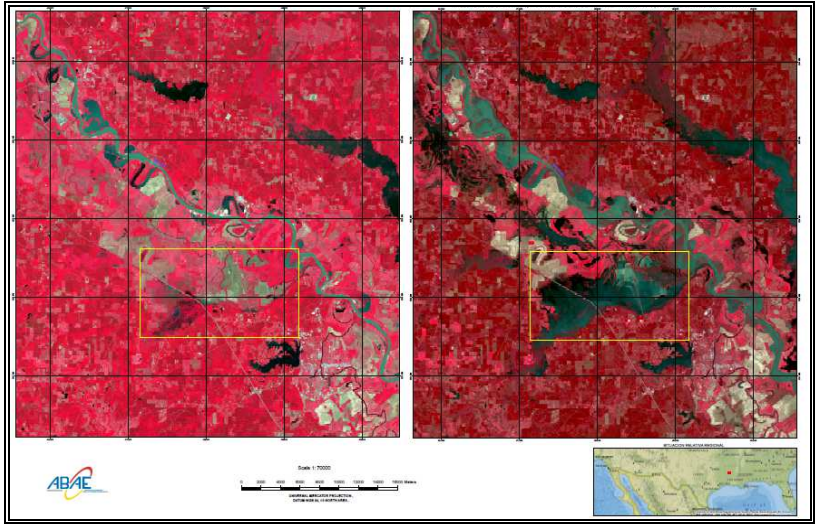

Figure $\mathrm{N}^{\circ}$ 6: Mississippi river flooding, occurred on January 2, 2016; affecting to Louisiana State sector- southeastern United States, using VRSS.1

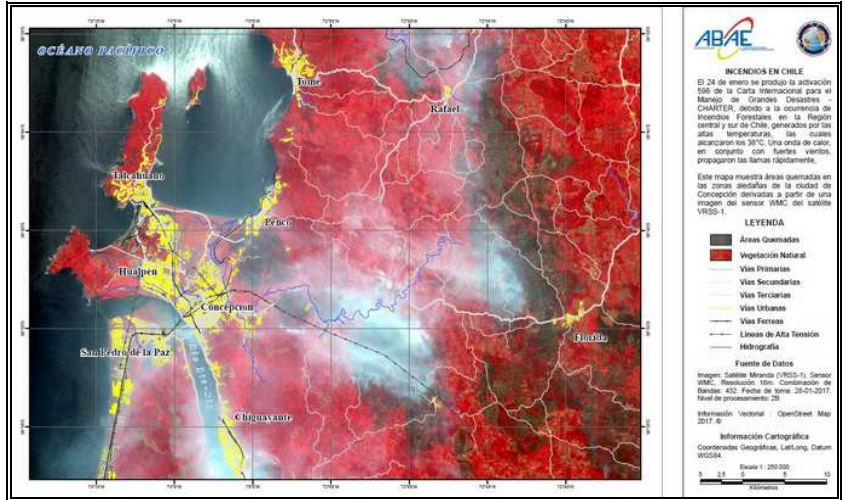

Figure $\mathrm{N}^{\circ}$ 7: Affected Areas by Fire - Chile, Feb, 2017, using VRSS.1 Image

The Venezuelan Space Program will provides to insert the VRSS-2 this year, whose information is also expected to be provided in the interests of the International Charter on Space and Major Disasters, thus stimulating our active participation in the Charter.

\section{DISCUSSION}

The Venezuelan space activity has grown rapidly in recent years thanks to international agreements with countries of major advances in the spatial field, where the technological transfer and training have played an essential role. The Venezuela space technology has shown an increasing interest in developing local space capabilities for peaceful purposes because it recognizes that, space technology and its spin-offs are powerful tools to develop industry and move the country's development forward. Furthermore, space applications in the areas of telecommunications, navigation and Earth observations can improve the living standards, connectivity, health and education of the people.

The ABAE and their space projects have served to increase the cooperation agreements with Latin America and the rest of the world, thanks to space police has promoted indigenous competences wherever possible, while also acknowledging the 
importance of the national Government to continue with the plans and space programs.

For the Bolivarian Republic of Venezuela and ABAE, international cooperation is one of the options for putting in place the infrastructure and human skills needed to enhance national space capabilities [17].

Developing countries with space capability must keep pushing their space industry development; there is great potential for investment from state and private sector. Rethinking Space Education objectives, with emphasis on Applications for the benefit of humanity, and think about: making the space activities sustainable on in developing countries.

We believe that those developing countries that acknowledge the economical importance and social impact derived from space capabilities, and invest in the aerospace sector today will be much more advanced both economically and technologically in the next couple of decades, thus bringing much more social welfare to their peoples.

\section{References}

[1] Acevedo R, Becerra R, Orihuela N, Varela F. "Space activities in the Bolivarian Republic of Venezuela", Space Policy, 27 (3), 2011, 174e179

[2] Agencia Bolivariana para Actividades Espaciales (ABAE). "Informe de Logros Institucionales" (Report on institutional achievements). ABAE Internal Report. Caracas, Venezuela; 2016.

[3] M. Imbert, Executive Director of Venezuela's Space Agency the Bolivarian Agency for Space Activities (ABAE for its acronym in Spanish). "Venezuela Space Cooperation, Applications and Perspectives". International Conference. Beijing 2016.

[4] V. Cano, President of Venezuela's Space Agency the Bolivarian Agency for Space Activities (ABAE for its acronym in Spanish). "The Progress of space activities in the Bolivarian Republic of Venezuela. Final intership report". Beijing, China: International onference; 2016.

[5] Technology transfer is also said to be pursued in the Bolivarian and not the socalled traditional fashion, believed to exacerbate technological dependence. SeeIbarra C. En nuestro pais se hace transferencia tecnologica a la "bolivariana" MINCI.22 November 2007. Last accessed September 12, 2011 http://alopresidente.gob.ve/informacion/3/311/en_nuestro_pauns.html.

[6] M. Imbert, Executive Director of Venezuela's Space Agency the Bolivarian Agency for Space Activities. "Space Commercial Cooperation Seminar". CGWIC. Beijing October 2016.

[7] Agencia Bolivariana para Actividades Espaciales (ABAE). "Informe Proyecto de Telemedicina y Teleducación". ABAE technical report; 2014.

[8] Orihuela N. "Strategic guidelines for the creation of the National Space Plan". ABAE's Confidential Document. Caracas, Venezuela; 2006.

[9] Agencia Bolivariana para Actividades Espaciales (ABAE). "Informe de Logros Institucionales" (Report on institutional achievements). ABAE Internal Report. Caracas, Venezuela; 2016

[10] V. Cano J. President of Venezuela's Space Agency the Bolivarian Agency for Space Activities. "International Congress of Geomatics", Caracas 2015 .

[11] M. Andrade. Director of International Affairs of ABAE. "Informe de logros Institucionales". (Report on institutional achievements). ABAE Internal Report Caracas, Venezuela 2016.

[12] P. Kansakar and F Hossain. "A review of applications of satellite earth observation data for global societal benefit and stewardship of planet earth". Volume 36, May 2016, Pages 46-54.
[13] Constitución de la República Bolivariana de Venezuela. Caracas: República Bolivariana de Venezuela, 1999. Last accessed 12 September 2015.http://www.gobiernoenlinea.gob.ve/home/archivos/ConstitucionR BV1999.pdf.

[14] M. Andrade. Director of International Affairs of ABAE. "December monthly internal report". Caracas, Venezuela 2017.

[15] M. Andrade. Director of International Affairs of ABAE. " Interview with the National Telecommunications Commission" (CONATEL for its acronym in Spanish). Caracas, Venezuela 2017

[16] M. Dominguez. Head of the Department of Earth observation of ABAE. "February monthly internal report". Caracas, Venezuela 2017.

[17] Acevedo Galindo R. The consolidation of space activities in the Bolivarian Republic of Venezuela. Final internship report. Strasbourg, France: International Space University; 2008. 